\title{
Research on the Impacts of Rural-to-Urban Migration on Demographic Characteristics Regarding Economic Development in Madagascar
}

\author{
Jeremy Desiré Rakotonirina*, Jinhua Cheng \\ School of Economics and Management, China University of Geosciences, Wuhan, China \\ Email: “iierui6@yahoo.fr
}

Received 22 April 2015; accepted 2 June 2015; published 5 June 2015

Copyright (C) 2015 by authors and Scientific Research Publishing Inc.

This work is licensed under the Creative Commons Attribution International License (CC BY).

http://creativecommons.org/licenses/by/4.0/

(c) (i) Open Access

\section{Abstract}

This paper described the situation of rural-urban migration. People of Madagascar are moving to Antananarivo to be settling in the capital cities to enjoy more facilities of life as compared to life in rural areas. In the present time, we can see that a big portion of world's population is living in urban sides. Over 90 percent of urbanization is taking place in developing countries, and is mainly focused amongst young grown-ups. Migration is the drive of publics from one topographical location to another, connecting temporary or permanent settlement. Although rural-urban immigration is the drive of publics from rural areas (villages) to urban centers (cities). A case study design was embraced in this research. Antananarivo was selected as a case study. The data for this study were mainly collected from the people who migrated from all over the Madagascar to Antananarivo, the capital of country, for different purposes. Most of the people migrated from the rural areas. A casual sample method was used to select the defendants. A total of 120 respondents were complicated in the study. All questionnaires were analyzed with frequencies rate one by one. At the end of this paper, conclusion and suggestion have been carried out by this research.

\section{Keywords}

Migration, Antananarivo, Madagascar, Urban, Rural

\section{Introduction}

In the present time, we can see that a big portion of world's population is living in urban sides. Over 90 percent

${ }^{*}$ Corresponding author.

How to cite this paper: Rakotonirina, J.D. and Cheng, J.H. (2015) Research on the Impacts of Rural-to-Urban Migration on Demographic Characteristics Regarding Economic Development in Madagascar. American Journal of Industrial and Business Management, 5, 335-350. http://dx.doi.org/10.4236/ajibm.2015.56034 
of urbanization is taking place in the developing countries, and is mainly focused amongst young grown-ups (aged 15 - 30 years) in Asia and Africa. The consequence of quick population development happened during the mid-twentieth period [1] [2]. Forecasts for Madagascar, presently one of the least developed countries in the realm, point out that the quantity of people existing in urban centers will be dual in the next forty years (from $17 \%$ in 2010 to $38 \%$ in 2050) [1]. In attitude, cities offer a more promising location for undertaking social and health hitches than rural sides. Metropolises provide income and jobs, and health care, and deliver education and other services more professionally than less thickly settled areas, just because of their compensations of scale and vicinity [3]. Though, in less advanced countries such as Madagascar, rapid urbanization is progressively intent poverty, placing strain on substructure and already strained public services in municipalities and metropolises [4]-[6]. A key task for the next century is managing the scale and pace of expansion, predominantly in countries which have scarcer possessions and leisurelier rates of financial development [7] [8]. This paper delivers a review of the works on the growth influence of immigration and payments on origin republics and on terminus countries. International immigration has growth implications for origin and destination countries. 215 million people ( 3 percent of the world's population) are supposed to live external their countries of birth [9]. While the focus in the literature has been on South-North migration, the number of immigrants among emerging countries is projected to be as large as the number of immigrants stirring from South to North [10]. Therefore, the expansion insinuations of relocation and the need to accomplish in-migration are as relevant to the South as they are to the North. Though vehement battle, partisan harassment, and trading are important reasons for worldwide flexibility, more than 9 out of 10 worldwide migrants move for economic reasons. By and large, relocation has optimistic economic influences on the migrant domestic, the transfer country as well as the getting country.

\section{Literature Review}

Migration is the drive of publics from one topographical location to alternative, connecting temporary or permanent settlement. The area where publics are departure is mentioned to as the basis area while the area to which publics are incoming is recognized as destination area. Although rural-urban immigration is the drive of publics from rural areas (villages) to urban centers (cities). One obvious feature in the civilization today is the percentage at which publics migrate from the rural to the urban centers. Though the urban centers are cumulative in populace, the rural areas are declining in populace. The immigration works has come to favor rural-urban migration as "the major contributing factor to the ubiquitous phenomenon of urban surplus labour and as a force which continues to exacerbate already serious urban unemployment problems" [11]. Populace development in urban parts has flown over the last few periods. For example, the United Nations leaflets that $40 \%$ of the total minimum advanced country's populace existed in urban areas in 2000 , likened to $26.1 \%$ in 1975 . More exactly, $34 \%$ of the 2000 Sub-Saharan African populace was urban-a jump of more than $62 \%$ over the 15 years [12]. As per Cornwell and Inder (2004) much of the modern literature on financial motivations for rural-urban immigration figures on the influential work of Todaro (1969) and Harris and Todaro (1970). Their replicas has providing a extensively acknowledged hypothetical framework that clarified the connection between rural-urban migration and urban joblessness in many LDCs. Supposing possible migrants reply to the urban employment possibility and giving rural-urban migration mainly as an economic spectacle, the Harris-Todaro model (HT) then proves that, in convinced parametric varieties, an growth in urban employ may essentially result in higher planes of urban joblessness and even concentrated nationwide produce (the Todaro Paradox). The irony is due to the expectations that in selecting between labor marketplaces, risk-neutral mediators reflect probable salaries; that the possibility of finding urban employment is approached by the relation of urban jobs to the urban labor force; and that the urban salary rate is significantly and reliably higher than the rural salary rate. Below these expectations, inter-labor market (rural-urban) symmetry commands urban joblessness. This joblessness guarantees that the predictable urban salary is equivalent to the rural salary (which is assumed constant throughout). The consequence of this humble set of expectations is that conflicting to conventional wisdom, once the immigration reply is factored in, several rules aimed at dropping urban joblessness will raise urban joblessness rather than decrease it [13]. In the HT model immigration is observed as the modification instrument by which work forces as sign themselves between dissimilar labor markets, some of which are situated in urban areas and some in rural areas, though trying to exploit their predictable profits. The model controlled to many practical studies most of which long-established that the comparative salaries and the apparent likelihood of outcome a job were certainly important elements of a choice to move. From the theoretic point of view, the model plants its lashing force, the 
difference of urban and rural salaries and the fixity of urban salary, mysterious. Though, the model, without or with fixed salaries, can be improved in a number of customs to familiarize many stimulating features (priority hiring, risk aversion, travel costs informal sector), which perhaps will decrease the level of joblessness as forecast by the preliminary classic. One of the estimates of HT model was that the comparative symmetry size of the urban outdated sector will differ contrariwise with the rate of job formation. Arellano (1981) [14] designated that this estimate rises to the stable state and is defensible by a specific supposition about the bounciness of the immigration rate. The Harris-Todaro model, called after John R. Harris and Michael Todaro, is an economic model developed in 1970 and castoff in progress economics and prosperity economics to clarify some of the matters regarding rural-urban immigration. The foremost notion of the model is that the immigration choice is established on predictable income differences among urban and rural zones reasonably than just salary differences. This suggests that rural-urban immigration in a framework of high urban joblessness can be frugally rational if predictable urban income surpasses predictable rural income. In the model, symmetry is extended when the predictable salary in urban areas is equivalent to the bordering produce of an unindustrialized worker. The model undertakes that joblessness is non-existent in the rural unindustrialized sector. It is also supposed that rural unindustrialized production and the successive labor market is dreamily modest. As a result, the unindustrialized rural salary is equal to unindustrialized marginal efficiency. In symmetry, the rural to urban immigration rate will be zero since the predictable rural income matches the predictable urban income. Though, in this symmetry there will be optimistic joblessness in the urban sector. The notion of this model is idealistic [15]. One restraint of this model is that it undertakes possible immigrants are risk impartial, as in they are unsympathetic between a certain predictable rural income and an unreliable predictable urban income of the same scale. This notion's reflection of financial realities is doubtful; poor immigrants will probably be possibility opposed and need a meaningfully better predictable urban income to migrate. However, the Harris-Todaro model can be familiar to imitate risk dislike through change of the predictable urban income cunning. In this study is remarkable in numerous features. Mainly, like numerous emerging countries, the difficulties of joblessness and deficiency has initiated to arise in Madagascar due to quick expansion in the last two periods, along with other evils such as a liberal overfilling of housing and social facilities, enlarged crime, contamination, and mobbing. Specified the thoughtful evils, it is necessary for us to know the influences subsidizing to the urbanization and city ward immigration so that agreeing policies may be derivative.

\section{Study Area}

In the present study we analyzed the migration and its effect on the economically and socially situation of Madagascar. Currently the migration rate from other cites to capital city Antananarivo is very high. The Republic of Madagascar is a country located in Eastern Africa, consisting of the world's fourth largest island and some smaller islands in the Indian Ocean. Madagascar has a coastal plain, high plateau and mountains. Major rivers include the Betsiboka, Onilahy, Mangoky and Tsiribihina. The east coast of Madagascar has lowlands leading to steep bluffs and central highlands. The Tsaratanana Massif in the north has volcanic mountains. The west coast has many protected harbors and broad plains, while the southwest is a plateau and desert region. The largest city and capital is Antananarivo. Other important cities are Antsirabe, Mahajanga and Toamasina. Highest peak is the Maromokotro reaching 2876 meters above sea level (Figure 1).

\section{Methodology}

A case study design was embraced in this research Antananarivo was selected as a case study. The data for this study were mainly collected from the people who migrants from all over the Madagascar to Antananarivo the capital of country for different purpose most of the people migrant from rural. A casual sample method was used to select the defendants. A total of 120 respondents were complicated in the study. Primary data for the study were collected by using organized questionnaires. Secondary data were got from current literature. The collected data were analyzed with the help of SPSS, frequencies of all questions discussed in detail for to check the reason and impacts of migration respondents. Questions almost covered all kind of basic and important information about the migration and its reasons. The questions were very easy and significant for checking the relation of all variable, and the questionnaires consisted of 39 questions, further it was divided into four parts the migration, urban housing condition, integration in the urban labor market and household and modernity. The demographic information of all respondents also included which was gender and marital status. 


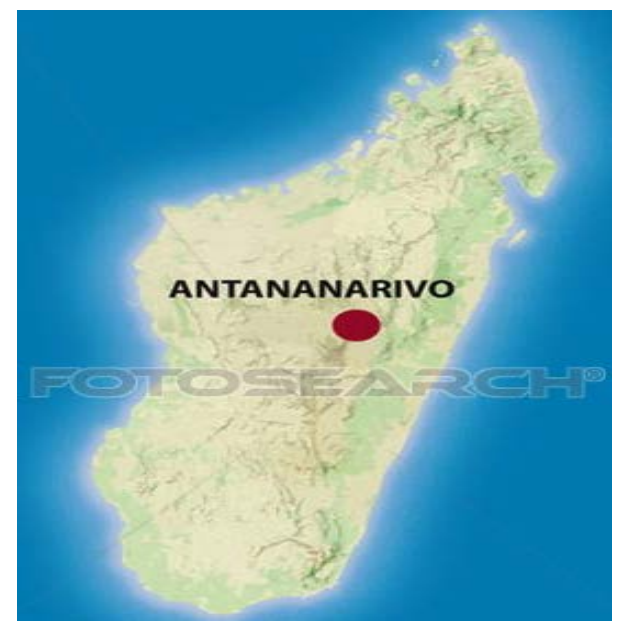

Figure 1. Antananarivo location, capital of Madagascar.

\section{Results and Discussions}

\subsection{The Migration}

The first portion of questionnaire was migration in this portion the detail was about basic information of migrators and its family and reason of migration etc. Q1 your first time to "Antananarivo as a migrant is" can be seen in Table 1, maximum number of people migrant after 2000 (Table 1). Q2 "Are you left "alone" or "with your family" Alone $60.8 \%$ and with family $39.2 \%$ (Table 2). Q3 "Where do you live during your arrival?" Family 42.5\%, Tenant 34.2\%, Owner 6.7\% and Employer 16.7\% (Table 3). Q4 "What reasons led you to immigrate in Antananarivo?" Jobs $28.3 \%$, Affectation $24.2 \%$, Study $20.0 \%$, Hardness $10.8 \%$, Vacanses $5.8 \%$ and Other $10.8 \%$ (Table 4). Q5 "What activities you practice in the countryside?" Agriculture 19.2\%, Student $24.2 \%$, Leaving school 6.7\%, Official 22.5\%, Unemployed14.2\% and others Other 13.3\% (Table 5). Q6 "Do you feel good here?" yes 72.5\% and no 27.5\% (Table 6). Q7 "Do you have specific reasons to live here (in Antananarivo)?" yes 74.2\% and no 25.8\% (Table 7). Q8 "Gender" Male 61.7\% and Female 38.3\% (Table 8). Q9 "Where do you come from?” Antsiranana 9.2\%, Mahajanga 6.7\%, Toamasina12.5\%, Antananarivo 28.3\%, Fianarantsoa 12.5\% and Toliara 30.8\% (Table 9).

\subsection{Urban Housing Condition}

Second portion was urban housing condition, this portion consisted questions about conditions of homes and facilities in home of urban. Q10 “Are you "tenant" or "Owner?" Tenant 66.7\% and Owner 33.3\% (Table 10). Q11 "What type of house?" Wood 20.0\% and Brick 80.0\% (Table 11). The Q12, Q13 and Q14 "In how many pieces do you live?" and "How many people live in this house?" and "Rent" can be seen clearly in Tables 12-14. Q15 "Do you drinking clean water from JIRAMA at home?" yes 60\% and no 40\% (Table 15). Q16 "Do you have electricity from JIRAMA at home?" yes $95 \%$ and no 5\% (Table 16). Q 17 "For cooking, what you use?" Charcoal 64.2\%, Wood 8.3\%, Gas 23.3\% and Power 4.2\% (Table 17).

\subsection{Integration in the Urban Labor Market}

Third portion integration in the urban labor market was about the information of respondents their age, marital status, education and salary etc. Q18 was about the age of migrants which can be seen in detail in Table 18. Q 19 "Marital status" single 44.2\%, Married 46.7\%, and Unmarried 9.2\% (Table 19). Q20 "Before you migrate, did you already have job to do in the city?" yes $25.0 \%$, no $71.7 \%$ and others 3.3\% (Table 20). Q21 "What job practices you currently?" No $10.0 \%$, Student $14.2 \%$, Civil servant $20.0 \%$, Self-employed $31.7 \%$, Private employed 20.8\% and Other 3.3\% (Table 21). Q22 "Have you followed worldwide training in town?" yes 34.2\%, no $65.0 \%$ and others $0.8 \%$ (Table 22). Q23 "Type of training? Academic 10.0\%, Public 10.0\%, Professional $25.0 \%$ and No idea $55.0 \%$ (Table 23). Q24 "What degree (level) do you have?" None 7.5\%, Cepe 8.3\%, Bepc 17.5\%, Bacc 25.0\%, Licence 22.5\%, Master 17.5\% and Doctorate 1.7\% (Table 24). Q 25 "How are you paid? 
Days 9.2\%, Per month 67.5\% and Family support 23.3\% (Table 25). Q 26 was about the salary amount which can be seen in detail Table 26. Q27 "In your opinion, is this stable job? Yes 46.7\%, no 37.5\% and others $15.8 \%$ (Table 27). Q 28 "Income, daily household expenditure (average) can be seen in Table 28. Q29 "Are you thinking to change jobs?" yes $40.0 \%$, no $48.3 \%$ and students $11.7 \%$ (Table 29). Q 30 "if yes" No choice $58.3 \%$, Private 23.3\%, Civil servant 8.3\% and Others 9.2\% (Table 30). Q31 "Your spouse (spouse) is he/she working?" Yes $46.7 \%$, No $45.0 \%$ and Nought $8.3 \%$ (Table 31 ).

\subsection{Household and Modernity}

The fourth and last portion was about household and modernity, covered the areas like Q32 is about children of migrants "How many children do you have?" (Table 32). Q33 "In what school your children continue its study? Public 25.0\%, Private 38.3\% and No idea 36.7\% (Table 33). Q34 "Education of children: How far do you think it is enough?" can been seen in Table 34. Q35 "What kind of distraction you give yourself during weekends?" Table 35. Q36 "Are you going on holiday? Yes 63.3\%, no 25.8\% and Child only 10.8\% (Table 36). Q37 "In a month, how much time do you spend in the countryside?" none $46.7 \%$, once per month $29.2 \%$, twice a month or more $15.8 \%$ and rarely $8.3 \%$ (Table 37 ). Q38 "Currently, do you practice the exhumation?" yes $54.2 \%$, no 40.0 and others5.8 (Table 38). Q39 "Do you want to return to the countryside? Yes 45.8\% and no 50.8\% (Table 39). This study is very important for to check the relation of migration with economics and its overall impacts, in the present study the maximum people which moved to capital city were after 2000. If we see there are maximum people who moved were alone, it's showed that people also want to kept relation with their previous villages, that's why they left their families over there and they can visit their hometown. The maximum numbers migrated due to job and study, so Government should try to provide more job chances and quality education in small cities and villages too so that people can lead their life in hometown peacefully, it will help to decrease urbanization too. Maximum people felt good in capital city because there they can enjoy more facilities. As per gender consideration, male are more than fifty percent who moved to capital cities, its mean their families' wives and children are still in hometown. Home made in capital cities are with bricks and maximum people do not have their home there so they need to take home on rent it is also a pressure and extra burden on them. So it's mean a big portion of their income they spent on rent but if we see there are people enjoying more facilities like electricity, gas, education prospective and jobs. If we see almost more than fifty percent people wanted to return their home town. This study was limited in the people from whole countries to the capital city of Madagascar has been discussed.

\section{A. The migration:}

\begin{tabular}{|cccccc}
\hline \multicolumn{7}{|l}{ Table 1. Your first time to Antananarivo as a migrant is? } \\
\hline \begin{tabular}{cccccc}
\hline \\
Year
\end{tabular} & Frequency & Percent & Year & Frequency & Percent \\
\hline 1893 & 1 & 0.8 & 2000 & 8 & 6.7 \\
1953 & 3 & 2.5 & 2001 & 1 & 0.8 \\
1976 & 1 & 0.8 & 2002 & 5 & 4.2 \\
1978 & 1 & 0.8 & 2003 & 10 & 8.3 \\
1980 & 4 & 3.3 & 2004 & 3 & 2.5 \\
1983 & 2 & 1.7 & 2005 & 2 & 1.7 \\
1984 & 1 & 0.8 & 2006 & 9 & 7.5 \\
1988 & 1 & 0.8 & 2007 & 4 & 3.3 \\
1990 & 3 & 2.5 & 2008 & 7 & 5.8 \\
1991 & 2 & 1.7 & 2009 & 6 & 5.0 \\
1993 & 5 & 4.2 & 2010 & 14 & 11.7 \\
1996 & 4 & 3.3 & 2011 & 9 & 7.5 \\
1998 & 4 & 3.3 & 2012 & 4 & 3.3 \\
1999 & 2 & 1.7 & 2013 & 4 & $\mathbf{1 0 0 . 0}$ \\
\hline
\end{tabular}


Table 2. Are you left "alone" or "with your family"?

\begin{tabular}{cccccc}
\hline & & Frequency & Percent & Valid Percent & Cumulative Percent \\
\hline \multirow{2}{*}{ Q2 } & Alone & 73 & 60.8 & 60.8 & 60.8 \\
& Family & 47 & 39.2 & 39.2 & 100.0 \\
& Total & 120 & 100.0 & 100.0 & \\
\hline
\end{tabular}

Table 3. Where do you live during your arrival?

\begin{tabular}{|c|c|c|c|c|c|}
\hline & & Frequency & Percent & Valid Percent & Cumulative Percent \\
\hline & Family & 51 & 42.5 & 42.5 & 42.5 \\
\hline & Tenant & 41 & 34.2 & 34.2 & 76.7 \\
\hline \multirow[t]{3}{*}{ Q3 } & Owner & 8 & 6.7 & 6.7 & 83.3 \\
\hline & Employer & 20 & 16.7 & 16.7 & 100.0 \\
\hline & Total & 120 & 100.0 & 100.0 & \\
\hline
\end{tabular}

Table 4. What reasons led you to immigrate in Antananarivo?

\begin{tabular}{|c|c|c|c|c|c|}
\hline & & Frequency & Percent & Valid Percent & Cumulative Percent \\
\hline \multirow{7}{*}{ Q4 } & Jobs & 34 & 28.3 & 28.3 & 28.3 \\
\hline & Affectation & 29 & 24.2 & 24.2 & 52.5 \\
\hline & Study & 24 & 20.0 & 20.0 & 72.5 \\
\hline & Hardness & 13 & 10.8 & 10.8 & 83.3 \\
\hline & Vacanses & 7 & 5.8 & 5.8 & 89.2 \\
\hline & Other & 13 & 10.8 & 10.8 & 100.0 \\
\hline & Total & 120 & 100.0 & 100.0 & \\
\hline
\end{tabular}

Table 5. What activities you practice in the countryside?

\begin{tabular}{|c|c|c|c|c|c|}
\hline & & Frequency & Percent & Valid Percent & Cumulative Percent \\
\hline \multirow{7}{*}{ Q5 } & Agriculture & 23 & 19.2 & 19.2 & 19.2 \\
\hline & Student & 29 & 24.2 & 24.2 & 43.3 \\
\hline & Leaving school & 8 & 6.7 & 6.7 & 50.0 \\
\hline & Official & 27 & 22.5 & 22.5 & 72.5 \\
\hline & Unemployed & 17 & 14.2 & 14.2 & 86.7 \\
\hline & Other & 16 & 13.3 & 13.3 & 100.0 \\
\hline & Total & 120 & 100.0 & 100.0 & \\
\hline
\end{tabular}

Table 6. Do you feel good here?

\begin{tabular}{cccccc}
\hline & & Frequency & Percent & Valid Percent & 72.5 \\
Q6 & Yes & 87 & 72.5 & 27.5 & 100.0 \\
& No & 33 & 27.5 & 100.0 \\
\hline
\end{tabular}

Table 7. Do you have specific reasons to live here (in Antananarivo)?

\begin{tabular}{cccccc}
\hline & & Frequency & Percent & Valid Percent & 74.2 \\
Q7 & Yes & 89 & 74.2 & 25.8 & 100.0 \\
& No & 31 & 25.8 & 100.0 \\
\hline
\end{tabular}


J. D. Rakotonirina, J. H. Cheng

Table 8. Genders.

\begin{tabular}{cccccc}
\hline & & Frequency & Percent & Valid Percent & Cumulative Percent \\
\hline \multirow{2}{*}{ Q8 } & Male & 74 & 61.7 & 61.7 & 61.7 \\
& Female & 46 & 38.3 & 38.3 & 100.0 \\
& Total & 120 & 100.0 & 100.0 & \\
\hline
\end{tabular}

Table 9. Where do you come from?

\begin{tabular}{cccccc}
\hline & Frequency & Percent & Valid Percent & Cumulative Percent \\
\hline & Antsiranana & 11 & 9.2 & 9.2 & 9.2 \\
Mahajanga & 8 & 6.7 & 6.7 & 15.8 \\
Toamasina & 15 & 12.5 & 28.3 & 28.3 & 28.3 \\
& Antananarivo & 34 & 12.5 & 12.5 & 56.7 \\
& Fianarantsoa & 15 & 30.8 & 30.8 & 69.2 \\
& Toliara & 37 & 100.0 & 100.0 & 100.0 \\
\hline
\end{tabular}

\section{B. Urban housing condition:}

Table 10. Are you "tenant" or “owner"?

\begin{tabular}{cccccc}
\hline & & Frequency & Percent & Valid Percent & Cumulative Percent \\
\hline \multirow{3}{*}{ Q10 } & Tenant & 80 & 66.7 & 66.7 & 66.7 \\
& Owner & 40 & 33.3 & 33.3 & 100.0 \\
& Total & 120 & 100.0 & 100.0 & \\
\hline
\end{tabular}

Table 11. What type of house?

\begin{tabular}{cccccc}
\hline & & Frequency & Percent & Valid Percent & Cumulative Percent \\
\hline \multirow{3}{*}{ Q11 } & Wood & 24 & 20.0 & 20.0 & 20.0 \\
& Brick & 96 & 80.0 & 80.0 & 100.0 \\
& Total & 120 & 100.0 & 100.0 & \\
\hline
\end{tabular}

Table 12. In how many pieces do you live?

\begin{tabular}{|c|c|c|c|c|c|}
\hline & & Frequency & Percent & Valid Percent & Cumulative Percent \\
\hline \multirow{8}{*}{ Q12 } & 1 & 28 & 23.3 & 23.3 & 23.3 \\
\hline & 2 & 44 & 36.7 & 36.7 & 60.0 \\
\hline & 3 & 26 & 21.7 & 21.7 & 81.7 \\
\hline & 4 & 14 & 11.7 & 11.7 & 93.3 \\
\hline & 5 & 5 & 4.2 & 4.2 & 97.5 \\
\hline & 6 & 2 & 1.7 & 1.7 & 99.2 \\
\hline & 8 & 1 & .8 & .8 & 100.0 \\
\hline & Total & 120 & 100.0 & 100.0 & \\
\hline
\end{tabular}


Table 13. How many people live in this house?

\begin{tabular}{cccccc}
\hline & Frequency & Percent & Valid Percent & Cumulative Percent \\
\hline 1 & 14 & 11.7 & 11.7 & 11.7 \\
2 & 20 & 16.7 & 16.7 & 28.3 \\
3 & 22 & 18.3 & 18.3 & 46.7 \\
4 & 27 & 22.5 & 22.5 & 69.2 \\
& 5 & 15 & 12.5 & 12.5 & 81.7 \\
& 6 & 13 & 10.8 & 10.8 & 92.5 \\
\\
7 & 3 & 2.5 & 2.5 & 95.0 \\
& 13 & 2 & 1.7 & 1.7 & 96.7 \\
& 10 & 3 & 2.5 & 2.5 & 99.2 \\
\hline
\end{tabular}

Table 14. Rent.

\begin{tabular}{|c|c|c|c|c|c|}
\hline & & Frequency & Percent & Valid Percent & Cumulative Percent \\
\hline \multirow{19}{*}{ Q14 } & 20,000 & 1 & 0.8 & 1.2 & 1.2 \\
\hline & 30,000 & 4 & 3.3 & 4.7 & 5.8 \\
\hline & 35,000 & 2 & 1.7 & 2.3 & 8.1 \\
\hline & 40,000 & 7 & 5.8 & 8.1 & 16.3 \\
\hline & 50,000 & 11 & 9.2 & 12.8 & 29.1 \\
\hline & 60,000 & 15 & 12.5 & 17.4 & 46.5 \\
\hline & 70,000 & 5 & 4.2 & 5.8 & 52.3 \\
\hline & 80,000 & 3 & 2.5 & 3.5 & 55.8 \\
\hline & 85,000 & 1 & 0.8 & 1.2 & 57.0 \\
\hline & 90,000 & 3 & 2.5 & 3.5 & 60.5 \\
\hline & 100,000 & 14 & 11.7 & 16.3 & 76.7 \\
\hline & 120,000 & 2 & 1.7 & 2.3 & 79.1 \\
\hline & 140,000 & 2 & 1.7 & 2.3 & 81.4 \\
\hline & 150,000 & 4 & 3.3 & 4.7 & 86.0 \\
\hline & 180,000 & 1 & 0.8 & 1.2 & 87.2 \\
\hline & 200,000 & 6 & 5.0 & 7.0 & 94.2 \\
\hline & 250,000 & 3 & 2.5 & 3.5 & 97.7 \\
\hline & 300,000 & 1 & 0.8 & 1.2 & 98.8 \\
\hline & 400,000 & 1 & 0.8 & 1.2 & 100.0 \\
\hline \multirow{3}{*}{ Missing } & Total & 86 & 71.7 & 100.0 & \\
\hline & System & 34 & 28.3 & & \\
\hline & & 120 & 100.0 & & \\
\hline
\end{tabular}

Table 15. Do you drinking clean water from JIRAMA at home?

\begin{tabular}{cccccc}
\hline & & Frequency & Percent & Valid Percent & Cumulative Percent \\
\hline Q15 & Yes & 72 & 60.0 & 60.0 & 60.0 \\
& No & 48 & 40.0 & 40.0 & 100.0 \\
& Total & 120 & 100.0 & 100.0 \\
\hline
\end{tabular}


J. D. Rakotonirina, J. H. Cheng

Table 16. Do you have electricity from JIRAMA at home?

\begin{tabular}{cccccc}
\hline & & Frequency & Percent & Valid Percent & Cumulative Percent \\
\hline \multirow{4}{*}{ Q16 } & Yes & 114 & 95.0 & 95.0 & 95.0 \\
& No & 6 & 5.0 & 5.0 & 100.0 \\
& Total & 120 & 100.0 & 100.0 & \\
\hline
\end{tabular}

Table 17. For cooking, what do you use?

\begin{tabular}{|c|c|c|c|c|c|}
\hline & & Frequency & Percent & Valid Percent & Cumulative Percent \\
\hline \multirow{5}{*}{ Q17 } & Charcoal & 77 & 64.2 & 64.2 & 64.2 \\
\hline & Firewood & 10 & 8.3 & 8.3 & 72.5 \\
\hline & Gas & 28 & 23.3 & 23.3 & 95.8 \\
\hline & Electricity & 5 & 4.2 & 4.2 & 100.0 \\
\hline & Total & 120 & 100.0 & 100.0 & \\
\hline
\end{tabular}

\section{Integration in the urban labor market:}

Table 18. Age.

\begin{tabular}{|c|c|c|c|c|c|}
\hline & & Frequency & $\%$ & Valid Percent & Cumulative Percent \\
\hline & 16 & 3 & 2.5 & 2.5 & 2.5 \\
\hline & 18 & 3 & 2.5 & 2.5 & 5.0 \\
\hline & 20 & 4 & 3.3 & 3.3 & 8.3 \\
\hline & 21 & 5 & 4.2 & 4.2 & 12.5 \\
\hline & 23 & 3 & 2.5 & 2.5 & 15.0 \\
\hline & 24 & 8 & 6.7 & 6.7 & 21.7 \\
\hline & 25 & 12 & 10.0 & 10.0 & 31.7 \\
\hline & 26 & 8 & 6.7 & 6.7 & 38.3 \\
\hline & 27 & 9 & 7.5 & 7.5 & 45.8 \\
\hline & 28 & 11 & 9.2 & 9.2 & 55.0 \\
\hline & 29 & 4 & 3.3 & 3.3 & 58.3 \\
\hline & 30 & 8 & 6.7 & 6.7 & 65.0 \\
\hline & 33 & 3 & 2.5 & 2.5 & 67.5 \\
\hline & 35 & 5 & 4.2 & 4.2 & 71.7 \\
\hline & 36 & 1 & 0.8 & 0.8 & 72.5 \\
\hline & 37 & 2 & 1.7 & 1.7 & 74.2 \\
\hline \multirow[t]{17}{*}{ Q18 } & 38 & 1 & 0.8 & 0.8 & 75.0 \\
\hline & 40 & 5 & 4.2 & 4.2 & 79.2 \\
\hline & 43 & 2 & 1.7 & 1.7 & 80.8 \\
\hline & 45 & 1 & 0.8 & 0.8 & 81.7 \\
\hline & 47 & 1 & 0.8 & 0.8 & 82.5 \\
\hline & 49 & 2 & 1.7 & 1.7 & 84.2 \\
\hline & 50 & 2 & 1.7 & 1.7 & 85.8 \\
\hline & 52 & 1 & 0.8 & 0.8 & 86.7 \\
\hline & 53 & 1 & 0.8 & 0.8 & 87.5 \\
\hline & 55 & 3 & 2.5 & 2.5 & 90.0 \\
\hline & 56 & 1 & 0.8 & 0.8 & 90.8 \\
\hline & 58 & 2 & 1.7 & 1.7 & 92.5 \\
\hline & 59 & 3 & 2.5 & 2.5 & 95.0 \\
\hline & 60 & 2 & 1.7 & 1.7 & 96.7 \\
\hline & 61 & 1 & 0.8 & 0.8 & 97.5 \\
\hline & 65 & 3 & 2.5 & 2.5 & 100.0 \\
\hline & Total & 120 & 100.0 & 100.0 & \\
\hline
\end{tabular}


Table 19. Marital status.

\begin{tabular}{cccccc}
\hline & & Frequency & Percent & Valid Percent & Cumulative Percent \\
\hline \multirow{2}{*}{ Q19 } & Single & 53 & 44.2 & 44.2 & 44.2 \\
& Married & 56 & 46.7 & 46.7 & 90.8 \\
& unmarried & 11 & 9.2 & 9.2 & 100.0 \\
\hline
\end{tabular}

Table 20. Before you migrate, did you already have job to do in the city?

\begin{tabular}{|c|c|c|c|c|c|}
\hline & & Frequency & Percent & Valid Percent & Cumulative Percent \\
\hline \multirow{4}{*}{ Q20 } & Yes & 30 & 25.0 & 25.0 & 25.0 \\
\hline & No & 86 & 71.7 & 71.7 & 96.7 \\
\hline & Other & 4 & 3.3 & 3.3 & 100.0 \\
\hline & Total & 120 & 100.0 & 100.0 & \\
\hline
\end{tabular}

Table 21. What job practices you currently?

\begin{tabular}{cccccc}
\hline & & Frequency & Percent & Valid Percent & Cumulative Percent \\
\hline & No & 12 & 10.0 & 10.0 & 10.0 \\
Student & 17 & 14.2 & 14.2 & 24.2 \\
& Civil servant & 24 & 20.0 & 20.0 & 44.2 \\
& Self employed & 38 & 31.7 & 31.7 & 75.8 \\
& Private employed & 25 & 20.8 & 20.8 & 96.7 \\
& Other & 4 & 3.3 & 100.0 & 100.0 \\
\hline
\end{tabular}

Table 22. Have you followed worldwide training in town?

\begin{tabular}{cccccc}
\hline & & Frequency & Percent & Valid Percent & Cumulative Percent \\
\hline \multirow{4}{*}{ Q22 } & Yes & 41 & 34.2 & 34.2 & 34.2 \\
& No & 78 & 65.0 & 65.0 & 99.2 \\
& Other & 1 & 0.8 & 0.8 & 100.0 \\
\hline
\end{tabular}

Table 23. Type of training?

\begin{tabular}{cccccc}
\hline & Frequency & Percent & Valid Percent & Cumulative Percent \\
\hline & Academic & 12 & 10.0 & 10.0 & 10.0 \\
Q23 & Public & 12 & 10.0 & 10.0 & 20.0 \\
& Professional & 30 & 25.0 & 25.0 & 45.0 \\
& No idea & 66 & 55.0 & 55.0 & 100.0 \\
\hline
\end{tabular}


J. D. Rakotonirina, J. H. Cheng

Table 24. What degree (level) do you have?

\begin{tabular}{|c|c|c|c|c|c|}
\hline & & Frequency & Percent & Valid Percent & Cumulative Percent \\
\hline \multirow{8}{*}{ Q24 } & None & 9 & 7.5 & 7.5 & 7.5 \\
\hline & Cepe & 10 & 8.3 & 8.3 & 15.8 \\
\hline & Bepc & 21 & 17.5 & 17.5 & 33.3 \\
\hline & $\mathrm{Bac}$ & 30 & 25.0 & 25.0 & 58.3 \\
\hline & Licence & 27 & 22.5 & 22.5 & 80.8 \\
\hline & Master & 21 & 17.5 & 17.5 & 98.3 \\
\hline & Doctorate & 2 & 1.7 & 1.7 & 100.0 \\
\hline & Total & 120 & 100.0 & 100.0 & \\
\hline
\end{tabular}

Table 25. How are you paid?

\begin{tabular}{cccccc}
\hline & & Frequency & Percent & Valid Percent & Cumulative Percent \\
\hline \multirow{4}{*}{ Q25 } & Days & 11 & 9.2 & 9.2 & 9.2 \\
& Month & 81 & 67.5 & 67.5 & 76.7 \\
& Family support & 28 & 23.3 & 23.3 & 100.0 \\
Total & 120 & 100.0 & 100.0 & \\
\hline
\end{tabular}

Table 26. How much?

\begin{tabular}{|c|c|c|c|c|c|}
\hline & & Frequency & Percent & Valid Percent & Cumulative Percent \\
\hline \multirow{24}{*}{ Q26 } & 60,000 & 1 & 0.8 & 1.4 & 1.4 \\
\hline & 80,000 & 1 & 0.8 & 1.4 & 2.9 \\
\hline & 100,000 & 4 & 3.3 & 5.8 & 8.7 \\
\hline & 120,000 & 6 & 5.0 & 8.7 & 17.4 \\
\hline & 130,000 & 1 & 0.8 & 1.4 & 18.8 \\
\hline & 140,000 & 2 & 1.7 & 2.9 & 21.7 \\
\hline & 150,000 & 2 & 1.7 & 2.9 & 24.6 \\
\hline & 170,000 & 3 & 2.5 & 4.3 & 29.0 \\
\hline & 190,000 & 1 & 0.8 & 1.4 & 30.4 \\
\hline & 200,000 & 1 & 0.8 & 1.4 & 31.9 \\
\hline & 250,000 & 4 & 3.3 & 5.8 & 37.7 \\
\hline & 260,000 & 1 & 0.8 & 1.4 & 39.1 \\
\hline & 280,000 & 2 & 1.7 & 2.9 & 42.0 \\
\hline & 300,000 & 7 & 5.8 & 10.1 & 52.2 \\
\hline & 315,000 & 2 & 1.7 & 2.9 & 55.1 \\
\hline & 330,000 & 1 & 0.8 & 1.4 & 56.5 \\
\hline & 350,000 & 2 & 1.7 & 2.9 & 59.4 \\
\hline & 380,000 & 4 & 3.3 & 5.8 & 65.2 \\
\hline & 400,000 & 4 & 3.3 & 5.8 & 71.0 \\
\hline & 450,000 & 1 & 0.8 & 1.4 & 72.5 \\
\hline & 460,000 & 1 & 0.8 & 1.4 & 73.9 \\
\hline & 480,000 & 2 & 1.7 & 2.9 & 76.8 \\
\hline & 500,000 & 1 & 0.8 & 1.4 & 78.3 \\
\hline & 510,000 & 1 & 0.8 & 1.4 & 79.7 \\
\hline
\end{tabular}




\begin{tabular}{|c|c|c|c|c|c|}
\hline \multicolumn{6}{|l|}{ Continued } \\
\hline & 540,000 & 1 & 0.8 & 1.4 & 81.2 \\
\hline & 560,000 & 1 & 0.8 & 1.4 & 82.6 \\
\hline & 600,000 & 1 & 0.8 & 1.4 & 84.1 \\
\hline & 630,000 & 4 & 3.3 & 5.8 & 89.9 \\
\hline & 640,000 & 1 & 0.8 & 1.4 & 91.3 \\
\hline \multirow[t]{6}{*}{ Q26 } & 650,000 & 1 & 0.8 & 1.4 & 92.8 \\
\hline & 655,000 & 2 & 1.7 & 2.9 & 95.7 \\
\hline & 710,000 & 1 & 0.8 & 1.4 & 97.1 \\
\hline & 730,000 & 1 & 0.8 & 1.4 & 98.6 \\
\hline & 770,000 & 1 & 0.8 & 1.4 & 100.0 \\
\hline & Total & 69 & 57.5 & 100.0 & \\
\hline \multirow[t]{2}{*}{ Missing } & System & 51 & 42.5 & & \\
\hline & & 120 & 100.0 & & \\
\hline
\end{tabular}

Table 27. In your opinion, is this a stable job?

\begin{tabular}{|c|c|c|c|c|c|}
\hline & & Frequency & Percent & Valid Percent & Cumulative Percent \\
\hline \multirow{4}{*}{ Q27 } & Yes & 56 & 46.7 & 46.7 & 46.7 \\
\hline & No & 45 & 37.5 & 37.5 & 84.2 \\
\hline & Others & 19 & 15.8 & 15.8 & 100.0 \\
\hline & Total & 120 & 100.0 & 100.0 & \\
\hline
\end{tabular}

Table 28. Income, daily household expenditure (average) MGA/day.

\begin{tabular}{|c|c|c|c|c|c|}
\hline & & Frequency & Percent & Valid Percent & Cumulative Percent \\
\hline & 30,000 & 2 & 1.7 & 1.8 & 1.8 \\
\hline & 45,000 & 7 & 5.8 & 6.2 & 8.0 \\
\hline & 60,000 & 15 & 12.5 & 13.4 & 21.4 \\
\hline & 75,000 & 2 & 1.7 & 1.8 & 23.2 \\
\hline & 90,000 & 12 & 10.0 & 10.7 & 33.9 \\
\hline & 120,000 & 5 & 4.2 & 4.5 & 38.4 \\
\hline & 150,000 & 21 & 17.5 & 18.8 & 57.1 \\
\hline & 180,000 & 4 & 3.3 & 3.6 & 60.7 \\
\hline \multirow[t]{9}{*}{ Q28 } & 210,000 & 5 & 4.2 & 4.5 & 65.2 \\
\hline & 240,000 & 2 & 1.7 & 1.8 & 67.0 \\
\hline & 300,000 & 13 & 10.8 & 11.6 & 78.6 \\
\hline & 350,000 & 3 & 2.5 & 2.7 & 81.2 \\
\hline & 450,000 & 9 & 7.5 & 8.0 & 89.3 \\
\hline & 480,000 & 3 & 2.5 & 2.7 & 92.0 \\
\hline & 600,000 & 6 & 5.0 & 5.4 & 97.3 \\
\hline & 900,000 & 3 & 2.5 & 2.7 & 100.0 \\
\hline & Total & 112 & 93.3 & 100.0 & \\
\hline \multirow[t]{2}{*}{ Missing } & System & 8 & 6.7 & & \\
\hline & Total & 120 & 100.0 & & \\
\hline
\end{tabular}


J. D. Rakotonirina, J. H. Cheng

Table 29. Are you thinking to change jobs?

\begin{tabular}{cccccc}
\hline & Frequency & Percent & Valid Percent & Cumulative Percent \\
\hline \multirow{2}{*}{ Q29 } & Yes & 48 & 40.0 & 40.0 & 40.0 \\
& No & 58 & 48.3 & 48.3 & 11.7 \\
& Student & 14 & 11.7 & 100.0 \\
\hline
\end{tabular}

Table 30. If yes?

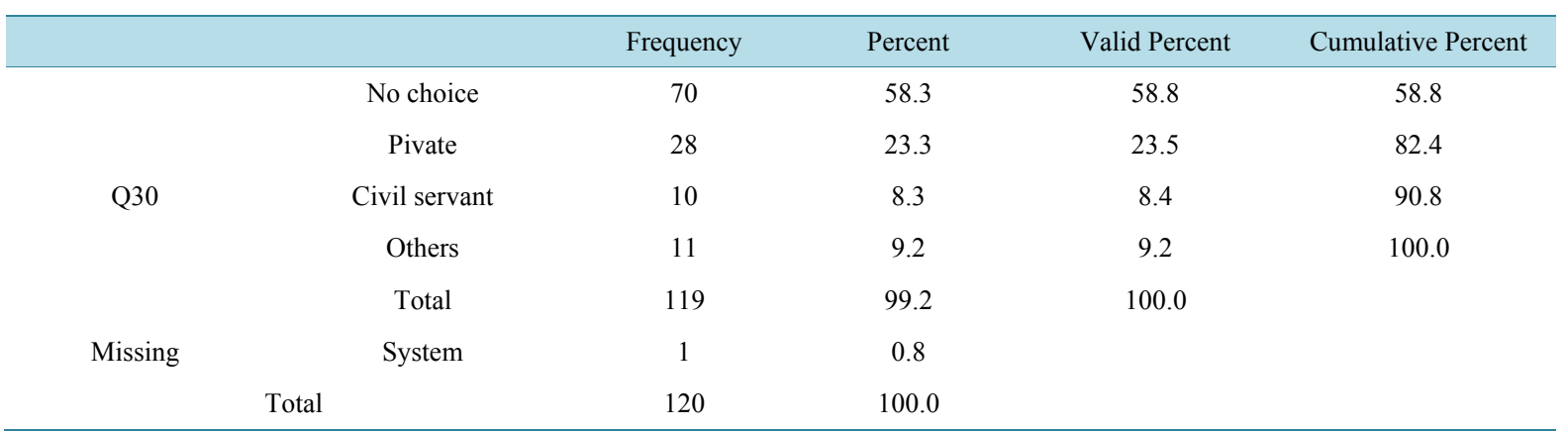

Table 31. Your spouse (spouse) is he/she working?

\begin{tabular}{cccccc}
\hline & Frequency & Percent & Valid Percent & Cumulative Percent \\
\hline \multirow{2}{*}{ Q31 } & Yes & 56 & 46.7 & 46.7 & 46.7 \\
& No & 54 & 45.0 & 45.0 & 8.3 \\
& Nought & 10 & 8.3 & 100.0 \\
\hline
\end{tabular}

\section{Household and modernity:}

Table 32. How many children do you have?

\begin{tabular}{|c|c|c|c|c|c|}
\hline & & Frequency & Percent & Valid Percent & Cumulative Percent \\
\hline & None & 57 & 47.5 & 47.9 & 47.9 \\
\hline \multirow{4}{*}{ Q32 } & {$[1 ; 3[$} & 38 & 31.7 & 31.9 & 79.8 \\
\hline & {$[3 ; 5[$} & 16 & 13.3 & 13.4 & 93.3 \\
\hline & {$[5 ;+[$} & 3 & 2.5 & 2.5 & 95.8 \\
\hline & 5 & 5 & 4.2 & 4.2 & 100.0 \\
\hline \multirow{3}{*}{ Missing } & Total & 119 & 99.2 & 100.0 & \\
\hline & System & 1 & 0.8 & & \\
\hline & & 120 & 100.0 & & \\
\hline
\end{tabular}

Table 33. In what school your children continue its study?

\begin{tabular}{cccccc}
\hline & & Frequency & Percent & Valid Percent & 25.0 \\
Public & 30 & 25.0 & 38.3 & 63.3 \\
Q33 & Private & 46 & 38.3 & 36.7 & 100.0 \\
& No Idea & 44 & 100.0 & 100.0 \\
\hline
\end{tabular}


Table 34. Education of children: how far do you think it is enough?

\begin{tabular}{|c|c|c|c|c|c|}
\hline & & Frequency & Percent & Valid Percent & Cumulative Percent \\
\hline \multirow{7}{*}{ Q34 } & No idea & 9 & 7.5 & 7.5 & 7.5 \\
\hline & Bepc & 4 & 3.3 & 3.3 & 10.8 \\
\hline & $\mathrm{Bac}$ & 21 & 17.5 & 17.5 & 28.3 \\
\hline & Licence & 31 & 25.8 & 25.8 & 54.2 \\
\hline & Master & 39 & 32.5 & 32.5 & 86.7 \\
\hline & Doctorate & 16 & 13.3 & 13.3 & 100.0 \\
\hline & Total & 120 & 100.0 & 100.0 & \\
\hline
\end{tabular}

Table 35. What kind of distraction you give yourself during weekends?

\begin{tabular}{|c|c|c|c|c|c|}
\hline & & Frequency & Percent & Valid Percent & Cumulative Percent \\
\hline \multirow{10}{*}{ Q35 } & Sport & 13 & 10.8 & 10.8 & 10.8 \\
\hline & Shopping & 10 & 8.3 & 8.3 & 19.2 \\
\hline & Watching TV & 21 & 17.5 & 17.5 & 36.7 \\
\hline & Picnic & 14 & 11.7 & 11.7 & 48.3 \\
\hline & Restauration & 18 & 15.0 & 15.0 & 63.3 \\
\hline & Sightseeing & 7 & 5.8 & 5.8 & 69.2 \\
\hline & Rest & 20 & 16.7 & 16.7 & 85.8 \\
\hline & Reading & 10 & 8.3 & 8.3 & 94.2 \\
\hline & Voyage & 7 & 5.8 & 5.8 & 100.0 \\
\hline & Total & 120 & 100.0 & 100.0 & \\
\hline
\end{tabular}

Table 36. Are you going on holiday?

\begin{tabular}{cccccc}
\hline & & Frequency & Percent & Valid Percent & Cumulative Percent \\
\hline \multirow{3}{*}{ Q36 } & Yes & 76 & 63.3 & 63.3 & 63.3 \\
& No & 31 & 25.8 & 25.8 & 89.2 \\
& Child only & 13 & 10.8 & 10.8 & 100.0 \\
\hline
\end{tabular}

Table 37. In a month, how much time do you spend in the countryside?

\begin{tabular}{cccccc}
\hline & & Frequency & Percent & Valid Percent & Cumulative Percent \\
\hline \multirow{4}{*}{ Q37 None } & 56 & 46.7 & 46.7 & 46.7 \\
& Once per month & 35 & 29.2 & 29.2 & 75.8 \\
& Twice per month or more & 19 & 15.8 & 15.8 & 91.7 \\
Rarely & 10 & 8.3 & 8.3 & 100.0 \\
\hline
\end{tabular}

Table 38. Currently, do you practice the exhumation?

\begin{tabular}{cccccc}
\hline & & Frequency & Percent & Valid Percent & Cumulative Percent \\
\hline & Yes & 65 & 54.2 & 54.2 & 40.0 \\
94.2 & 5.8 & 100.0 \\
& No & 48 & 5.8 & 100.0 & \\
\end{tabular}


Table 39. Do you want to return to the countryside?

\begin{tabular}{ccccccc}
\hline \multirow{2}{*}{ Q39 } & & Frequency & Percent & Valid Percent & Cumulative Percent \\
\hline \multirow{3}{*}{ Missing } & & Yes & 55 & 45.8 & 47.4 & 47.4 \\
& & No & 61 & 50.8 & 52.6 & 100.0 \\
& & Total & 116 & 96.7 & 100.0 & \\
& & System & 4 & 3.3 & & \\
& & & 120 & 100.0 & & \\
\hline
\end{tabular}

\section{Conclusions}

Madagascar is developing and trying to make improvement in every sector of life. More and more people are getting higher education, and after that, to make life more luxuries and satisfactory, they move to big cities to search good jobs with higher wages. The rate of rural-urban immigration is high in recent years and its possessions are not only touched by the terminus areas alone but also touched by the foundation regions, as services in the terminus regions are overstrained, and the source areas are virtually isolated. Lest the government delivers the basic supplies of life to the rural areas and deliver the creative youth in the rural areas with service chances people will unceasingly point in to the urban centers from the rural areas in search for improved life and occupation. Our questionnaire proves that maximum people are moving to the capital city for the purpose of jobs and if we see the basic facilities are also in urban areas, it's also one reason of maximum people moving to other cities. If Government tries to provide the same facilities all over the country, people will prefer to live in their present cities. Questionnaire proved that maximum people after migration tried to settle in Antananarivo and didn't want to go back because in Antananarivo they could enjoy more facilities and more opportunities about other things.

There should be more opportunities in rural areas too, like education, jobs, good medical treatment and basic need of life, so that people can spend their life happily in their respective places instead of moving to big cities, resulting in increased urbanization. The demographic significances of rural involvement initiatives are rarely measured, but it is vital that they should not be smallest as a means of measuring their continuing and wider efficiency. Population development, environmental deprivation and unexpected urban development have been decorated as the foremost influences obstructing supportable worldwide communal and financial development. Though separating the self-governing inspiration of these procedures is not informal, if the crucial tasks of the 21 st century narrate to populace pressures, we are essential to grow an improved sympathetic of the association between demography and expansion. This research has significance for growth policy-makers and manipulators. If populace development related with growth is powering recent rises in rural-urban immigration, then extra weight may be used on previously strained rural and urban facilities, though housing, jobs, and facilities are not obtainable to bear this drifting communal.

\section{References}

[1] UN (2011) World Population Prospects and World Urbanization Prospects: The 2011 Revision. Population Division of the Department of Economic and Social Affairs of the United Nations Secretariat.

[2] Hadley, C., Belachew, T., Lindstrom, D. and Tessema, F. (2011) The Shape of Things to Come? Household Dependency Ratio and Adolescent Nutritional Status in Rural and Urban Ethiopia. American Journal of Physical Anthropology, 144, 643-652. http://dx.doi.org/10.1002/ajpa.21463

[3] UNFPA (2007) State of World Population 2007: Unleashing the Potential of Urban Growth.

[4] UN-HABITAT (2008) Ethiopia: Urban Profile.

[5] Gurmu, E. (2005) Fertility Transition Driven by Poverty: The Case of Addis Ababa (Ethiopia). University of London, London.

[6] Byass, P., Berhane, Y., Emmelin, A. and Wall, S. (2003) Patterns of Local Migration and Their Consequences in a Rural Ethiopian Population. Scandinavian Journal of Public Health, 31, 58-62. http://dx.doi.org/10.1080/14034940210133726

[7] Cohen, J.E. (2003) Human Population: The Next Half Century. Science, 302, 1172-1175. http://dx.doi.org/10.1126/science.1088665

[8] World Bank (2009) Systems of Cities: Harnessing Urbanization for Growth and Poverty Alleviation. World Bank Ur- 
ban and Local Government Strategy, World Bank.

[9] United Nations (2009) International Migrant Stock: The 2008 Revision. United Nations Population Division. http://esa.un.org

[10] Ratha, D. and Shaw, W. (2007) South-South Migration and Remittances. World Bank Working Paper, No. 102, The World Bank.

[11] Todaro, M.P. (1976) Internal Migration in Developing Countries, International Labour Office, Geneva.

[12] Cornwell, K. and Inder, B. (2004) Migration and Unemployment in South Africa: When Motivation Surpasses the Theory. Monash University, Melbourne.

[13] Riadh, B.J. (1998) Rural-Urban Migration: On the Harris-Todaro Model. Maître de Conférences à l'Universitéde Bretagne Sud C.E.I.E

[14] Arellano, J.P. (1981) Do More Jobs in the Modern Sector Increase Urban Unemployment? Journal of Development Economics, 8, 241-247.

[15] Harris, J.R. and Todaro, M.P. (1970) Migration, Unemployment and Development: A Two-Sector Analysis. American Economic Review, 60, 126-142. 